\title{
Analisis Kemampuan Berpikir Kritis Matematis: Dampak Model Pembelajaran Problem Based Instruction
}

\author{
Suhita * \\ SMP Negeri 24, Jalan Prof.Dr.Hamka, Sukarame, Bandar Lampung 35133, Indonesia. \\ * Corresponding Author. E-mail: suhita1964@gmail.com
}

\begin{abstract}
Abstrak
Penelitian ini bertujuan untuk meningkatkan kemampuan berpikir kritis peserta didik melalui penerapan model pembelajaran Problem Based Instruction. Penelitian ini merupakan quasi eksperimen. Subjek penelitian dalam penelitian ini adalah peserta didik kelas VIIIA SMP Negeri 24 Bandar Lampung Tahun Pelajaran 2017/2018 dengan jumlah peserta didik sebanyak 32 peserta didik dengan teknik pengambilan sampel cluster random sampling. Data yang diperlukan diperoleh melalui observasi, dokumentasi dan tes menggunakan soal uraian. Data yang terkumpul dianalisis dengan teknik analisis kuantitatif. Adapun instrumen yang digunakan untuk mengumpulkan data adalah berupa tes kemampuan berpikir kritis. Data dari hasil tes dan lembar observasi dianalisis secara kuantitatif. Hasil penelitian menunjukkan bahwa kemampuan berpikir kritis peserta didik pada kelas kontrol sebesar 14,23\% dan termasuk ke dalam kategori rendah, sedangkan pada kelas eksperimen kemampuan berpikir kritis peserta didik mencapai 87,5\% atau termasuk kategori tinggi. Jadi, dapat dikatakan model pembelajaran Problem Based Instruction dapat meningkatkan kemampuan berpikir kritis peserta didik, dimana kemampuan berpikir kritis peserta didik meningkat dari setiap siklusnya. Sehingga model pembelajaran Problem Based Instruction ini bisa diterapkan dalam pembelajaran baik dalam pelajaran matematika maupun dalam pelajaran lain.
\end{abstract}

Kata kunci: Berpikir Kritis, Problem Based Instruction

\begin{abstract}
This study aims to improve students' critical thinking skills through the application of Problem Based Instruction learning models. This research is a quasi experiment. The research subjects in this study were students of class VIIIA SMP Negeri 24 Bandar Lampung Academic Year 2017/2018 with a total of 32 students with a cluster random sampling technique. The required data is obtained through observation, documentation and tests using description questions. The collected data was analyzed by quantitative analysis techniques. The instruments used to collect data are tests of critical thinking skills. Data from the test results and observation sheets were analyzed quantitatively. The results showed that students 'critical thinking skills in the control class were $14.23 \%$ and included in the low category, while in the experimental class students' critical thinking abilities reached $87.5 \%$ or included in the high category. So, it can be said that the Problem Based Instruction learning model can improve students 'critical thinking skills, where students' critical thinking abilities increase from each cycle. So that the Problem Based Instruction learning model can be applied in learning both in mathematics and in other lessons.
\end{abstract}

Keywords: Critical Thinking, Problem Based Instruction

\section{PENDAHULUAN}

Berpikir kritis adalah berpikir dengan baik, merenungkan tentang proses berpikir merupakan bagian dari berpikir dengan baik (Nafiah \& Suyanto, 2014). Berpikir kritis digunakan dalam kegiatan mental seperti memecahkan masalah, mengambil keputusan, menganalisis asumsi dan melakukan penelitian secara ilmiah (Farisi, Hamid, \& Melvina, 2017). Seseorang yang berpikir kritis dapat mengajukan pertanyaan yang tepat, memecahkan masalah yang diberikan, tidak serta merta hanya 
memindahkan informasi yang disampaikan oleh guru sehingga menjadikan peserta didik yang pasif.

Mengatasi permasalahan di atas, diperlukan suatu model pembelajaran yang dapat mengembangkan aktivitas dan kemampuan berpikir kritis peserta didik yang dapat berkembang dengan optimal, maka diperlukan model pembelajaran matematika yang tepat.

Kemampuan berpikir kritis matematis adalah suatu kecakapan berpikir secara efektif yang dapat membantu seseorang untuk membuat, mengevaluasi, serta mengambil keputusan tentang apa yang diyakini atau dilakukan (Jumaisyaroh, Napitupulu, \& Hasratuddin, 2014). Kemampuan berpikir kritis dapat dikembangkan atau diperkuat melalui proses pembelajaran. Tidak semua proses pembelajaran secara otomatis akan mengembangkan kemampuan berpikir kritis. Hanya proses pembelajaran yang mendorong diskusi dan banyak memberikan kesempatan berpendapat, menggunakan gagasan, memberikan banyak kesempatan kepada peserta didik untuk mengekspresikan gagasan-gagasan dalam tulisan, mendorong kerjasama dalam mengkaji dan menemukan pengetahuan, mengembangkan tanggung jawab, refleksi diri dan kesadaran sosial, yang akan mengembangkan berpikir kritis peserta didik. Salah satu model pembelajaran yang memiliki karakter tersebut ialah model pembelajaran Problem Based Learning (PBL) atau Pembelajaran Berbasis Masalah (Farisi et al., 2017).

Model pembelajaran Problem Based Instruction (PBI) merupakan model pembelajaran yang menggunakan suatu permasalahan di dalam kehidupan seharihari untuk diidentifikasi dan dipecahkan, tidak hanya terpusat pada penguasaan materi (Dewi, 2016). Menurut Dewey dalam (Nurhidayati, Agustin, S., Roemintoyo, \& Murtiono, 2013) pembelajaran berbasis masalah adalah interaksi antara stimulus dengan respons, merupakan hubungan antara dua arah belajar dan lingkungan. Lingkungan memberi masukan kepada siswa berupa bantuan dan masalah, sedangkan sistem saraf otak berfungsi menafsirkan bantuan itu secara efektif sehingga yang dihadapi dapat diselidiki, dinilai, dianalisis, serta dicari pemecahannya dengan baik.

Pengalaman peserta didik yang diperoleh dari lingkungan akan menjadikan bahan dan materi guna memperoleh pengertian yang bisa dijadikan pedoman dan tujuan belajar (Riyanto, 2009). Dalam proses pembelajaran yang menerapkan model pembelajaran Problem Based Instruction, peserta didik dihadapkan pada permasalahan dunia nyata yang tentunya dikaitkan dengan materi yang diajarkan oleh guru. Materi yang sesuai dengan model pembelajaran tersebut adalah materi yang berkaitan dengan permasalahan sehari-hari peserta didik sehingga akan memudahkan peserta didik dalam menerima materi pembelajaran.

Berdasarkan hasil observasi peneliti pada kondisi awal, menunjukkan bahwa pembelajaran Matematika di kelas VIII B terhadap 32 orang peserta didik SMP Negeri 24 Bandar Lampung, peserta didik mengalami kesulitan dalam memahami mata pelajaran matematika disebabkan karena kurang aktif, inovatif, dan kritis. Proses pembelajaran matematika di kelas kurang melibatkan interaksi dan aktivitas mental peserta didik. Hal ini terlihat menunjukkan bahwa nilai rata-rata hasil pre-test pada kondisi awal untuk materi garis dan sudut adalah 58,25, dengan capaian ketuntasan belajar hanya hanya $37,50 \%$ atau 12 peserta didik yang tuntas dengan memperoleh nilai $\mathrm{KKM} \geq 70$.

Berdasarkan penelitian terdahulu, model pembelajaran Problem Based Instruction banyak digunakan dalam proses pembelajaran dalam 
meningkatkan hasil belajar (Dewi, 2016; Hakim, Karyanto, \& Maridi, 2013; Putri, Fauzi, \& Murtiani, 2013; Susanti, Indrawati, \& Yushardi, 2015), keterampilan proses sains (Rusmiyati \& Yulianto, 2009), prestasi belajar \& kreativitas siswa (Utami, 2011) bahkan model pembelajaran PBI dapat membentuk kemandirian mahasiswa (Nurhidayati et al., 2013) serta meningkatkan personalisme guru (Winarsih \& Mulyani, 2012). Perbedannya adalah peneliti mencaritahu pengaruh model pembelajaran PBI dalam meningkatkan kemampuan berpikir kritis pada peserta didik.

Penelitian selanjutnya, menerapkan beberapa model atau metode pembelajaran, seperti inkuiri terbimbing (Hapsari, Sudarisman, \& Marjono, 2012; Sochibin, Dwijananti, \& Marwoto, 2009), Problem Based Learning (Aziz, Ahyan, \& Fauzi, 2016; Farisi et al., 2017; Kusumaningtias, Zubaidah, \& Indriwati, 2013; Nafiah \& Suyanto, 2014; Palennari, 2012; Setyorini, Sukiswo, \& Subali, 2011) serta project based learning (Daniel, 2016; Mahanal, Darmawan, Corebima, \& Zubaidah, 2009) berbasis masalah (Jumaisyaroh et al., 2014; Redhana, 2012) dan berbasis hands on activities (Yuliati, Yulianti, \& Khanafiyah, 2011) dalam meningkatkan kemampuan berpikir kritis pada peserta didik. Perbedannya adalah peneliti ingin mencari keterbaruan model pembelajaran yang tepat dalam meningkatkan kemampuan berpikir kritis, sehingga peneliti mencoba menggunakan model pembelajaran Problem Based Instruction dalam meningkatkan kemampuan berpikir kritis pada peserta didik.

Berdasarkan latar belakang masalah di atas, maka tujuan penelitian ini adalah untuk meningkatkan kemampuan berpikir kritis peserta didik melalui penerapan model pembelajaran Problem Based Instruction.

\section{METODE}

Metode yang diterapkan pada penelitian ini adalah metode Quasi eksperimen. Populasi penelitian ini adalah peserta didik kelas IX SMPN 24 Bandar Lampung. Sampel yang terpilih adalah kelas VIII B yang dipilih menggunakan tehnik acak kelas.

Model yang digunakan dalam pembelajaran adalah model Problem Based Instruction dalam pembelajaran matematika. Instrumen penelitian yang digunakan adalah tes kemampuan berpikir kritis peserta didik yang berupa pre-test dan post-test. Pengumpulan data pre test dan post test bertujuan untuk memperoleh data prestasi belajar peserta didik sebelum dan sesudah diberi perlakuan pembelajaran menggunakan model Problem Based Instruction. Pre test diberikan sebelum peserta didik mendapatkan perlakuan dan post test diberikan setelah peserta didik mendapatkan perlakuan. Model Problem Based Instruction akan dikatakan efektif apabila skor yang didapatkan dari hasil post test lebih dari atau sama dengan kriteria ketuntasan minimal, yaitu 75 . Penyekoran hasil tes dilakukan untuk mendapatkan data dari hasil tes dengan nilai minimal 0 dan nilai maksimal 100 .

\section{HASIL DAN PEMBAHASAN}

Berdasarkan hasil tes kemampuan berpikir kritis kelas kontrol, peserta didik seluruh peserta didik masuk dalam kategori sangat rendah. Adapun persentase kemampuan berpikir kritis peserta didik per-Indikator kemampuan berpikir kritis sebelum dilaksanakannya pembelajaran dengan menggunakan model pembelajaran Problem Based Instruction dapat dilihat pada Tabel 1 . 
Tabel 1. Persentase per-Indikator Kemampuan Berpikir Kritis Kelas Kontrol

\begin{tabular}{lcl}
\hline \multicolumn{1}{c}{ Indikator } & $\mathbf{\%}$ & \multicolumn{1}{c}{ Kategori } \\
Keterampilan memberikan penjelasakan yang sederhana & 30,21 & Sangat rendah \\
Keterampilan memberikan penjelasan lanjut & 6,51 & Sangat rendah \\
Keterampilan mengatur strategi dan taktik & 19,79 & Sangat rendah \\
Keterampilan menyimpulkan dan mengevaluasi & 0 & Sangat rendah \\
Rata-rata & $\mathbf{1 4 , 2 3}$ & Sangat rendah \\
\hline
\end{tabular}

Berdasarkan Tabel 1, terlihat bahwa kemampuan berpikir kritis peserta didik sebelum dilaksanakan pembelajaran dengan menggunakan model pembelajaran Problem Based Instruction diperoleh hasil sebagai berikut:

\section{a. Kemampuan keterampilan memberikan penjelasan yang sederhana}

Indikator ini melihat bagaimana peserta didik memberikan penjelasan sederhana terhadap suatu pertanyaan matematika. Persentase kemampuan peserta didik memberikan penjelasan sederhana secara tertulis sebesar 30,21\% dengan kategori sangat rendah. Hal ini diperoleh berdasarkan jumlah skor yang diperoleh oleh seluruh peserta didik pada indikator kemampuan keterampilan. Pada kelas kontrol, hanya sebagian peserta didik yang mampu memberikan penjelasan sederhana terhadap pertanyaan matematika yang diberikan.

\section{b. Kemampuan keterampilan}

Indikator ini melihat kemampuan peserta didik dalam memberikan penjelasan lanjut, persentasenya sebesar $6,51 \%$ dengan kategori sangat rendah. Hal ini diperoleh berdasarkan jumlah skor yang diperoleh oleh seluruh peserta didik pada indikator kemampuan keterampilan.

\section{c. Kemampuan keterampilan mengatur strategi dan taktik}

Indikator ini melihat kemampuan peserta didik dalam mengatur strategi dan taktik dalam menyelesaikan pertanyaan yang diberikan, presentase yang diperoleh sebesar 19,79\% dengan kategori Sangat rendah. Skor ini diperoleh berdasarkan jumlah skor yang diperoleh oleh seluruh peserta didik pada indikator kemampuan keterampilan mengatur strategi dan taktik.

d. Kemampuan keterampilan menyimpulkan dan mengevaluasi

Indikator ini melihat kemampuan peserta didik dalam menarik kesimpulan dari pernyataan yang diberikan dan mengevaluasi dengan persentase sebesar $0 \%$ dengan kategori sangat rendah. Hal ini diperoleh berdasarkan jumlah skor yang diperoleh oleh seluruh peserta didik pada indikator kemampuan peserta didik menarik kesimpulan dari pernyataan. Peserta didik kerapkali beranggapan kalau penarikan kesimpulan itu bukanlah hal yang penting.

Secara keseluruhan kemampuan berpikir kritis pada kelas kontrol termasuk dalam kategori sangat rendah dengan presentase sebesar 14,23\%. Persentase kemampuan berpikir kritis yang diperoleh peserta didik pada kelas eksperimen dapat dilihat pada Tabel 2 .

Tabel 2. Persentase per-Indikator Kemampuan Berpikir Kritis

Peserta Didik Kelas Eksperimen

\begin{tabular}{lll}
\hline \multicolumn{1}{c}{ Indikator } & \multicolumn{1}{c}{ \% } & \multicolumn{1}{c}{ Kategori } \\
Keterampilan memberikan penjelasan yang sederhana & 82,81 & Sedang \\
Keterampilan memberikan penjelasan lanjut & 93,75 & Sangat Tinggi \\
Keterampilan mengatur strategi dan taktik & 92,19 & Sangat Tinggi \\
Keterampilan menyimpulkan dan mengevaluasi & 81,25 & Sedang \\
Rata-rata & $\mathbf{8 7 , 5}$ & Tinggi \\
\hline
\end{tabular}


Berdasarkan Tabel 2, terlihat bahwa kemampuan berpikir kritis peserta didik setelah dilakukan pembelajaran dengan menggunakan model pembelajaran Problem Based Instruction memperoleh presentase sebagai berikut:

\section{a. Kemampuan keterampilan memberikan penjelasan yang sederhana}

Indikator ini melihat bagaimana peserta didik memberikan penjelasan sederhana terhadap suatu pertanyaan matematika. Persentase kemampuan peserta didik memberikan penjelasan sederhana secara tertulis sebesar $82,81 \%$ dengan kategori tinggi. Hal ini diperoleh berdasarkan jumlah skor seluruh peserta didik pada indikator memberikan penjelasan sederhana terhadap pertanyaan matematika. Pada tes yang diberikan hampir semua peserta didik mampu memberikan penjelasan yang sederhana.

\section{b. Kemampuan keterampilan memberikan penjelasan lanjut}

Indikator ini melihat kemampuan peserta didik dalam memberikan penjelasan lanjut, persentasenya sebesar 93,75\% dengan kategori sangat tinggi. Hal ini diperoleh berdasarkan jumlah skor yang diperoleh oleh seluruh peserta didik pada indikator kemampuan keterampilan memberikan penjelasan lanjut.

\section{c. Kemampuan keterampilan mengatur strategi dan taktik}

Indikator ini melihat kemampuan peserta didik dalam mengatur strategi dan taktik dalam menyelesaikan pertanyaan yang diberikan, persentase yang diperoleh sebesar 92,19\% dengan kategori sangat tinggi. Skor ini diperoleh berdasarkan jumlah skor yang diperoleh oleh seluruh peserta didik pada indikator kemampuan keterampilan mengatur strategi dan taktik.
d. Kemampuan
keterampilan menyimpulkan dan mengevaluasi

Indikator ini melihat kemampuan peserta didik dalam menarik kesimpulan dari pernyataan yang diberikan dan mengevaluasi dengan persentase sebesar $81,25 \%$ dengan kategori tinggi.

Secara keseluruhan kemampuan berpikir kritis peserta didik kelas VIII B SMP Negeri 24 Bandar Lampung termasuk dalam kategori tinggi dengan presentase sebesar $87,5 \%$.

\section{SIMPULAN DAN SARAN}

Berdasarkan analisis hasil penelitian, dapat ditarik kesimpulan bahwa penerapan model pembelajaran Problem Based Instruction dapat meningkatkan kemampuan berpikir kritis. Hal ini ditunjukkan dengan aktivitas siswa pada kelas eksperimen yang menggunakan model pembelajaran Problem Based Instruction sudah dapat dikategorikan baik karena waktu yang digunakan untuk melakukan setiap kategori aktivitas siswa sesuai dengan alokasi waktu yang termuat dalam Rencana Pelaksanaan Pembelajaran.

$$
\text { Berdasarkan dari hasil }
$$

kesimpulan, maka peneliti memberikan saran yaitu seharusnya lembaga pendidikan atau sekolah menerapkan model pembelajaran Problem Based Instruction sebagai salah satu alternatif dalam proses belajar mengajar sehingga dapat meningkatkan kemampuan berpikir kritis peserta didik dalam proses pembelajaran.

\section{DAFTAR PUSTAKA}

Aziz, A., Ahyan, S., \& Fauzi, L. M. (2016). Implementasi Model Problem Based Learning (PBL) dalam Meningkatkan Kemampuan Berpikir Kritis Mahasiswa melalui Lesson Study. Jurnal Elemen, 2(1), 83-91.

Daniel, F. (2016). Kemampuan Berpikir Kritis Siswa Pada Implementasi Project Based Learning (Pjbl) 
Berpendekatan Saintifik. Jurnal Pendidikan Matematika Indonesia, 1(1), 7-13.

Dewi, T. A. (2016). Penerapan Model Problem Based Instruction untuk Meningkatkan Hasil Belajar Mahasiswa pada Mata Kuliah Ekonomi Pembangunan. Jurnal Promosi, 4(1), 35-45.

Farisi, A., Hamid, A., \& Melvina. (2017). Pengaruh Model Pembelajaran Problem Based Learning terhadap Kemampuan Berpikir Kritis dalam Meningkatkan Hasil Belajar Siswa pada Konsep Suhu dan Kalor. Jurnal Ilmiah Mahasiswa (JIM) Pendidikan Fisika, 2(3), 283-287.

Hakim, L., Karyanto, P., \& Maridi. (2013). Pengaruh Model Pembelajaran Problem Based Instruction Disertai Media Audio Visual Terhadap Hasil Belajar Biologi Siswa Kelas X SMA Negeri 1 Ngemplak Tahun Pelajaran 2011/2012. Pendidikan Biologi, 5(1), 49-58.

Hapsari, D. P., Sudarisman, S., \& Marjono. (2012). Pengaruh Model Inkuiri Terbimbing dengan Diagram V (Vee) dalam Pembelajaran Biologi terhadap Kemampuan Berpikir Kritis dan Hasil Belajar Siswa. Pendidikan Biologi, 4(3), 16-28.

Jumaisyaroh, T., Napitupulu, E. E., \& Hasratuddin. (2014). Peningkatan Kemampuan Berpikir Kritis Matematis dan Kemandirian Belajar Siswa SMP melalui Pembelajaran Berbasis Masalah. Jurnal Kreano, 5(2), 157-169.

Kusumaningtias, A., Zubaidah, S., \& Indriwati, S. E. (2013). Pengaruh Problem Based Learning DIPAdu Strategi Numbered Heads Together terhadap Kemampuan Metakognitif, Berpikir Kritis, dan Kognitif Biologi. Jurnal Penelitian Kependidika, 23(1), 33-47.

Mahanal, S., Darmawan, E., Corebima, ) A D, \& Zubaidah, S. (2009). Pengaruh
Pembelajaran Project Based Learning (PJBL) pada Materi Ekosistem terhadap Sikap dan Hasil Belajar Siswa SMAN 2 Malang.

Nafiah, Y. N., \& Suyanto, W. (2014). Penerapan Model Problem-Based Learning untuk Meningkatkan Keterampilan Berpikir Kritis dan Hasil Belajar Siswa. Jurnal Pendidikan Vokasi, 4(1), 125-143.

Nurhidayati, A., Agustin, R. S., S., T. L. A., Roemintoyo, \& Murtiono, E. S. (2013). Penerapan Model Pembelajaran Problem Based Instruction sebagai Upaya Pembentukan Kemandirian Mahasiswa pada Mata Kuliah Teknik Pondasi. JIPTEK, VI(1), 69-75.

Palennari, M. (2012). Potensi Integrasi Problem Based Learning dengan Pembelajaran Kooperatif Jigsaw dalam Meningkatkan Keterampilan Berpikir Kritis Mahasiswa. Jurnal Bionature, 13(1), 1-9.

Putri, A. M., Fauzi, A., \& Murtiani. (2013). Pengaruh Lks Bertampilan Komik Terhadap Hasil Belajar IPA Fisika Siswa dalam Pembelajaran Problem Based Instructionmateri Gelombang Bunyi dan Optika di Kelas VIII SMPN 3 Bukittinggi. Pillar of Physics Education, 2, 137-144.

Redhana, I. W. (2012). Model Pembelajaran Berbasis Masalah dan Pertanyaan Socratik untuk Meningkatkan Keterampilan Berpikir Kritis Siswa. Cakrawala Pendidikan, XXXI(3), 351-365.

Riyanto, Y. (2009). Paradigma Baru Pembelajaran. Jakarta: Rineka Cipta.

Rusmiyati, A., \& Yulianto, A. (2009). Peningkatan Keterampilan Proses Sains dengan Menerapkan Model Problem Based-Instruction. Jurnal Pendidikan Fisika Indonesia, 5, 7578.

Setyorini, U., Sukiswo, S. E., \& Subali, B. (2011). Penerapan Model Problem Based Learning untuk Meningkatkan 
Kemampuan Berpikir Kritis Siswa SMP. Jurnal Pendidikan Fisika Indonesia 7, 7, 52-56.

Sochibin, A., Dwijananti, P., \& Marwoto, P. (2009). Penerapan Model Pembelajaran Inkuiri Terpimpin untuk Peningkatan Pemahaman dan Keterampilan Berpikir Kritis Siswa SD. Jurnal Pendidikan Fisika Indonesia, 5, 96-101.

Susanti, E. D., Indrawati, \& Yushardi. (2015). Pengaruh Model Pembelajaran Problem Based Instruction Disertai Metode Demonstrasi terhadap Hasil Belajar Dan Retensi Hasil Belajar Siswa Pada Pembelajaran Fisika Sma (Studi Pada Kelas X MIA SMAN Arjasa Jember). Jurnal Pembelajaran Fisika, 4(3), 255-260.
Utami, R. P. (2011). Pengaruh Model Pembelajaran Search Solve Create and Share (SSCS) dan Problem Based Instruction (PBI) Terhadap Prestasi Belajar dan Kreativitas Siswa. Bioedukasi, 4(2), 57-71.

Winarsih, A., \& Mulyani, S. (2012). Peningkatan Profesionalisme Guru IPA Melalui Lesson Study dalam Pengembangan Model Pembelajaran PBI. Jurnal Pendidikan IPA Indonesia, 1(1), 43-50.

Yuliati, D. I., Yulianti, D., \& Khanafiyah, S. (2011). Pembelajaran Fisika Berbasis Hands on Activities untuk Menumbuhkan Kemampuan Berpikir Kritis dan Meningkatkan Hasil Belajar Siswa SMP. Jurnal Pendidikan Fisika Indonesia, 7, 2327. 